\title{
Tájváltozás, tájhasználat és az ideális méhlegelő dél- dunántúli méhészek szemével
}

\author{
Arany Ildikó ${ }^{1,2}$, Czúcz Bálint ${ }^{1,3}$, Csonka Imre ${ }^{4}$, Kovács-Hostyánszki \\ Anikó ${ }^{1}$ és Molnár Zsolt ${ }^{1}$ \\ ${ }^{1}$ MTA Ökológiai Kutatóközpont, \\ 8237 Tihany, Klebelsberg Kuno u. 3. \\ ${ }^{2}$ Szent István Egyetem, Környezettudományi Doktori Iskola, \\ 2100 Gödöllö, Páter Károly u. 1. \\ ${ }^{3}$ European Topic Centre on Biological Diversity, Muséum national d'Histoire naturelle, \\ FR-75231 Paris, 57 rue Cuvier, , Paris Cedex 05, France \\ ${ }^{4}$ Országos Magyar Méhészeti Egyesület, \\ 1094 Budapest, Viola u. 50. \\ e-mail:arany.ildiko@,okologia.mta.hu
}

\begin{abstract}
Összefoglaló: Milyen az ideális méhlegelö táj? Milyen ehhez képest a jelenlegi helyzet, hogyan lehetne azt jobbá tenni, és mindez milyen természetvédelmi következményekkel járna? Erről kérdeztünk meg 129 méhészt a 2015-ös Dunántúli Regionális Méhésztalálkozón, Kaposváron. A fö bevételi forrást adó szántóföldi kultúrákon és erdőkön túl a válaszadók többsége kiemelten fontosnak tartotta a vadvirágok sokféleségét fenntartó változatos élöhelyek szerepét a méhcsaládok egészséges önfenntartásához. A méhészek néhány konkrét kezelési javaslatot is megfogalmaztak a méhlegelő értékének javítása érdekében, pl. természetközeli élőhelyek helyreállítását, méhlegelő fajok tudatos vetését és a szántók zöldítését. A javasolt kezelések egy része nemcsak méhészeti, hanem természetvédelmi szempontból is kedvező hatású lehet, mert elősegíti a faji és élőhelyi szintủ diverzitást mind a háziméhek, mind a vad beporzó rovarok számára.
\end{abstract}

Kulcsszavak: háziméh, beporzás, invazív növényfajok, intenzív mezőgazdálkodás, fajgazdagság, élőhelyi sokféleség, helyi tudás

\section{Bevezetés}

A mezőgazdaság nagymértékben függ a beporzó rovarok tevékenységétől, a termesztett növényfajoknak a 70 százaléka ugyanis rovarbeporzású. A rovarbeporzás globálisan egyre inkább kritikus helyzetbe kerül (Stoate et al. 2009, Clough et al. 2014), a vadon élő beporzó rovarok sokfélesége és egyedszáma jelentős mértékben csökken, és a háziméhek mérgezése, a méhcsaládok egészségi álla- 
potának romlása is egyre gyakoribb jelenség Európában és Észak-Amerikában (Vandenberg 2013). A beporzás védelme ezért mára szakpolitikai célként jelent meg (Potts et al. 2016a), és a méhek, és általában a méhészet szerepe világszinten felértékelödött. Ha a természetvédelmi célok minél megalapozottabb megfogalmazására törekszünk, akkor az akadémiai és a szakpolitikai tudást fontos kiegészíteni a különböző érintettek helyi tudásával, ezért a velük való párbeszéd lényeges eleme a folyamatnak (Mihók et al. 2016). Magyarországon is elindult ez a párbeszéd több érintett csoport bevonásával, de a méhészek részvétele az eddigi kutatásokban és szakpolitikai folyamatokban nem volt hangsúlyos, holott az ő tudásuk nem csak a háziméhek, de - hasonló ökológiai igényeik révén - a vad beporzó rovarok kapcsán felmerülő természetvédelmi problémák megoldásához is felbecsülhetetlen (Lehébel-Péron et al. 2016, Maderson \& Wynne-Jones 2016).

A háziméhek (Apis mellifera L.), ha tehetik, változatos faji összetételü virágokat látogatnak, ezáltal nemcsak a méhcsalád kiegyensúlyozott táplálékellátását biztosítják, hanem reprodukciójának optimális feltételeit is (Decourtye et al. 2011). Míg az 1950-es évek előtt a hazai méhészek legnagyobbrészt vegyes virágmézet pergettek, azt követően egyre hangsúlyosabb méhészeti szerepet kapott az akác (Robinia pseudoacacia L.), a nagyüzemi mezőgazdálkodás elterjedésével pedig a napraforgó (Helianthus annuus L.) és a repce (Brassica napus L.) (Nagy 2005). Az intenzív mủvelésủ szántók és ültetvények a fő termények virágzási idejében bőséges, de egyoldalú táplálékforrást nyújtanak, ugyanakkor élőhelyi és faji diverzitásuk Európa-szerte nagymértékben csökkent. A mezőgazdasági gyomnövények sokfélesége például az utóbbi 70 év alatt 50\%-kal esett vissza (Bretagnolle \& Gaba 2015). Ez a visszaesés különösen a termények virágzási periódusai közötti időszakokban érinti a méhészeket hátrányosan, hiszen ezekben az időszakokban a méhek étrendjének akár 40\%-át is kiteheti gyomnövényekről gyüjtött pollen (Requier et al. 2015). Érdemes a mezőgazdasági gyomok közül is kiemelni a tarlóvirágot (Stachys annua L.), amely az 1950-es évekig az egyik legfontosabb mézelő növény volt Magyarországon, ám mára drámai mértékben visszaszorult (Pinke \& Pál 2009).

A virággazdagság csökkenésével párhuzamosan megjelentek és elterjedtek olyan inváziós növényfajok, amik jó mézelöknek bizonyultak, és részben helyettesíteni tudták a ritkuló vadvirágokat. Ilyen fajok például a selyemfü (Asclepias syriaca L.) vagy a gyalogakác (Amorpha fruticosa L.). A méhészek alkalmazkodtak a megváltozott körülményekhez, a vadvirágos élöhelyekröl egyre inkább áttértek a nagy, de időben koncentrált nektár- és virágporhozamú, fajokban szegény méhlegelőkre és inváziós fajok állományaira. A kilencvenes évektöl a méhészet egyre több leszakadó térségben nyújtott helyi megélhetési lehetőséget (EC 2013), az 1995-ös 600.000 körüli méhcsaládszám mára több, mint 1 millióra nőtt (Kecs- 
kés \& Kulcsár 2002, Zilahy 2012). A méhészet még ma is jellemzően kiegészítő jövedelem, de a professzionális, 150 méhcsaládnál többet tartó méhészek száma is nő (Kecskés \& Kulcsár 2002, Zilahy 2012). Magyarország éves méztermelése ma 20.000 tonna körül mozog, amivel az EU egyik legjelentősebb méztermelő országa, 2009-ben 27 EU tagország méztermelésének 10,8\%-át adta (Zilahy 2012). Az utóbbi 10 évben a kereskedelmi forgalomba kerülő méz 30-50\%-a (a tavaszi időjárástól függően) akácméz, de szintén magas, 10-30\% közötti a napraforgóés a repceméz aránya, a régen meghatározó vegyes virágméz ezzel szemben 10$20 \%$-ra szorult vissza. A fennmaradó 10\% körüli mennyiséget fajtaméz különlegességek - pl. a hárs (Tilia spp.), a selyemfü, a szelídgesztenye (Castanea sativa Mill.), a facélia (Phacelia tanacetifolia Benth.) vagy az aranyvessző - teszik ki (Zilahy 2012). A modern méhészeti technikák termelékenyebbek a hagyományos módszereknél, ugyanakkor a mai méhésznek számos új betegséggel, kórokozóval és környezeti ártalommal kell szembenéznie (Tóth 2012).

Felmérésünk célja az volt, hogy megtudjuk, hogyan látják a dél-dunántúli méhészek az utóbbi három évtized tájváltozását, és ehhez hogyan alkalmazkodtak: miről gyüjtenek a méheik, milyen növényekre vándorolnak velük, és milyen növényfajok hiányoznak a méhek hosszú távú önfenntartásához és egészségéhez. Arra is kíváncsiak voltunk, hogy milyen javaslataik vannak a méhlegelők értékének javítása érdekében. A kutatással árnyalni kívántuk azt az ellentmondást, ami a méhészet és a természetvédelem közötti, az akác és egyéb inváziós fajok kapcsán kialakult érdekellentét és az ugyanezen szektorok közötti, a vadvirágok és élőhelyek sokféleségét támogató közös érdek között húzódik. Mindezzel a két szektor közötti párbeszédhez, egyensúly kereséséhez, a konfliktusok mérsékléséhez kívántunk hozzájárulni.

\section{Módszerek}

Hazai összehasonlításban a Dél-Alföld mellett a Dél-Dunántúl a legjobb méhlegelőkkel ellátott régió, itt található a legtöbb méhcsalád is (2011-ben a hazai méhcsaládok 20,3\%-a) és itt a legnagyobb az egy méhészetre jutó méhcsaládok átlagos száma (63) (Zilahy 2012). Baranya, Somogy és Zala után az ország második és harmadik legnagyobb méhsürüségủ megyéje, egy négyzetkilométerén több mint 16 méhcsalád él (Tóth 2012). A régió legnagyobb kierjedésủ méhlegelő területei az erdők (kb. 350.000 hektár), de jelentős repce (kb. 40.000 hektár) és napraforgó (kb. 53.000 hektár) terület is található itt (Zilahy 2012). A Dunántúlidombság régió természetessége összességében az országos átlagnak megfelelö, a középrégiók szintjén Külső-Somogy az országos átlag alatti, míg Belső-So- 
mogy, a Mecsek és Tolna-Baranyai-dombvidék középrégió kevéssel az országos szint fölötti, de jóval alacsonyabb a legtermészetesebb középhegységi régióknál (Czúcz et al. 2008). Az említett különbségek a különböző mezőgazdasági potenciált, a települések sürüségét, az infrastruktúra kiépítettségét és a természetközeli élőhelyek arányát tükrözik.

Hipotézisünk a következő volt: az ideális méhlegelő egyszerre nyújt időszakosan nagy nektár- és virágporforrást, valamint a virágok folyamatosan elérhető sokféleségét, ezáltal biztosítva a mézhozamot és a méhek saját tápanyag-szükségleteit a vegetációs időszak egészében. Mindez egy olyan mozaikos, élőhelyekben és fajokban gazdag tájat feltételez, amely egyúttal a társadalmi-ökológiai rendszerek hosszú távú fenntarthatóságának is kulcsa, a táji szintü természetvédelemnek pedig célkitüzése.

A fenti hipotézis részvételi megközelítésű tesztelésére egy bevezető előadást (Molnár et al. 2015) követően kérdőíves adatgyüjtést végeztünk a 17. Dunántúli Regionális Méhésztalálkozó során, 2015. január 24-én, Kaposváron. A kérdőív első részében a válaszadók méhészeti tevékenységével kapcsolatos általános információkra - lakóhelyére, életkorára, méhcsaládjainak számára és vándorlási szokásaira - kérdeztünk rá. A kérdőív második, tartalmi része 19 kérdésből állt, amelyek közül tanulmányunk szempontjából az alábbi 5 kérdés volt releváns:

- A háziméhek, a méhészkedés szempontjából hogyan változott a táj, a határ amióta méhészkedik? Sorolja fel a 4 legfontosabb változást.

- Milyen virágra vándorolt az utóbbi években, illetve 10-30 évvel ezelőtt?

- Soroljon föl „vad”, vagyis nem termesztett méhlegelő növényeket, amelyekre a méhei rendszeresen járnak, illetve jártak!

- $\quad$ Milyen növények hiányoznak a méheinek június-szeptember között?

- Hogyan lehetne a méhlegelő nyári-ősz eleji hiányát orvosolni?

Az öt kérdés mindegyike nyílt volt, vagyis nem voltak előre megadott válaszlehetőségek. A válaszok értékelése az 1-es kérdés esetében kvalitatív módon történt. A válaszadók maximum 4, méhészeti szempontból relevánsnak ítélt megfigyelést adhattak meg. A 129 válaszadó összesen 251 rövid szöveges választ adott. Ebből 8 választ nem tudtunk értelmezni, ezért kizártunk a további elemzésből. A maradék 243 választ 7 fó témakörbe soroltuk, ezeket a könnyebb hivatkozhatóság érdekében 1A-1G kóddal jelöljük. A válaszok többsége néhány, bizonyos ökoszisztémában vagy táji szinten jellemző tendenciát jelez. Az elemzés során ezeket a fö ökoszisztémákat és tendenciákat azonosítottuk és csoportokba rendeztük. Az elemzési módszer korlátjaként említhető, hogy a válaszokat egységesen értékeltük ki. A fó tendenciák talán a leginkább egyértelmúen ezen a módon látszanak, ugyanakkor tisztában vagyunk ennek leegyszerüsítő jellegével, hiszen a táj változásának percepciója bizonyos mértékben változó lehet a méhészek körében a 
méhészek korára, a méhészkedés módjára és a méhészet méretére vonatkozó háttértényezők függvényében. Az eredmények ilyen irányú finomítására ugyanakkor véleményünk szerint nagyobb szakmai rendezvényeken történő kérdőívek helyett kisebb csoportos műhelymunkát vagy személyes interjúkat érdemes készíteni.

A 2. kérdés témája a dél-dunántúli méhészek vándorlásának célfajai voltak. A kérdés két részből állt: a 10 évnél hosszabb ideje méhészkedőket arra kértük, hogy az elmúlt 10 év és az azt megelőző 20 év vándorlási szokásait külön is jelezzék. A 10 évnél rövidebb ideje méhészkedők csak az első részkérdésre válaszoltak. Az egyes növényfajokra kapott eredményeket az adott időszakban aktívan vándorló méhészek százalékában adtuk meg.

A 3. kérdés a méhek által a jelenben vagy a múltban látogatott vadon élö növények felsorolását kérte, míg a 4. kérdésben arra kértük a méhészeket, hogy sorolják fel, milyen (termesztett vagy vad) növényeket látnának szívesen nagyobb mennyiségben a nyári nektárhiányos időszakban. Mindkét kérdés esetében az egyes fajokat megjelölő válaszadók számát összesítettük.

Az 5. pontban a méhlegelő nyári-ösz elejei hiányának orvoslására vonatkozó nyitott kérdést tettünk fel. A válaszok elemzésének módszere az 1. kérdés elemzésével megegyező módon történt. A válaszok sok esetben komplexek voltak, több különböző javaslatot tartalmaztak. Ezeket a válaszokat javaslatokra bontottuk, és az így azonosított 135 javaslatot csoportosítottuk 5 fó téma szerint, $5 \mathrm{~A}-5 \mathrm{E}$ kóddal jelölve.

\section{Eredmények}

Összesen 129 méhész töltötte ki a kérdőívet, akiknek a többsége, 122 fő 4 megyéből érkezett: Somogy megyéből 65, Baranya megyéből 23, Zala megyéből 22 és Tolna megyéből 12 fö. Rajtuk kívül további 6 fó vett részt a felmérésben, 1 Vas megyei, 2 Fejér megyei, 2 Bács-Kiskun megyei és 1 Pest megyei méhész, további 1 résztvevő pedig nem adott meg magáról erre vonatkozó információt. A válaszok elemzésekor megállapított tendenciákat a Dél-Dunántúl (Somogy, Baranya és Tolna megye) táji adottságainak viszonylatában értelmeztük, mert a válaszadók 78\%-a ezt a régiót képviselte. Ugyanakkor fontos megemlíteni, hogy - mivel ehhez nem mindig voltak elég pontos információink - az eredmények interpretációjához nem használtunk a régiós szintnél finomabb térbeli felbontást.

A válaszadók kiegyensúlyozott arányban képviselték a kisebb és nagyobb méhészeteket, közülük 41 méhész 50-nél kevesebb, 42 méhész 50 és 100 közötti, 45 méhész pedig több mint 100 méhcsaláddal gazdálkodott (itt is volt $1 \mathrm{db}$ hiányos válasz). A válaszadók életkorának medián értéke 55 év, a legidősebb 87 éves volt, 
míg a legfiatalabb 20 éves. A 129 fő közül 65 fő nem folytatott vándorlást, 58 fö vándorolt méheivel. Az utóbbi csoporton belül 20-an vándoroltak 100 km-nél is messzebbre, 27-en maximum 20 és $100 \mathrm{~km}$ közötti távolságokra és 11-en 20 km-en belüli távolságokra. 6 fő nem adott magáról a vándorlásra vonatkozó információt.

Az alábbiakban részleteztük az egyes kérdésekre adott válaszok kiértékelésének eredményeit. Az 1. és 5. kérdés esetében az eredményeket a kérdőívekből származó szöveges válaszok közül vett példákkal illusztráltuk, ezeket idézőjelben és dőlt betüvel jelöltük.

\section{Tájváltozás a méhészkedés szempontjából}

$\mathrm{Az}$ 1. kérdésre adott válaszok nagy része (56) az agrártáj, ezen belül is a (1A) szántóföldek (szántóföldi művelés vagy szántóföldi termesztett és vad növények) változását emeli ki. A következő tendenciák azonosíthatók: a szántók területe növekedett más élőhelyek, különösen a legelők rovására. A szántók müvelési módja megváltozott: a monokultúrás, intenzív, kemizált nagytáblás gazdálkodás aránya nőtt; megjelent a (korai) tarlóhántás és mélyszántás; a vetésforgó ritkább lett. A szántóföldi termények aránya és ezáltal a szántók átlagos méhlegelö értéke csökkent: több kukoricát, búzát, napraforgót, repcét és kevesebb pillangóst vetnek. A repce és napraforgó egyes modern fajtái nem mézelnek. Megritkultak a szántóföldi gyomnövények, kiemelten a tarlóvirág.

"A szántóföldek a nádasig, vízpartig érnek., "mezögazdasági növénytermesztés egyhangúsága"

A szántókkal közel azonos számú (55) válasz jelölte meg tájváltozási tényezőként (1B) a természetes és természetközeli, fátlan illetve átmeneti jellegü élőhelytípusok eltünését, illetve sokféleségüknek és méhlegelő-értéküknek a csökkenését. A cserjések, vizes élőhelyek, rétek, kaszálók, legelők, útszélek, árokpartok és szegélyek ritkábbá váltak. Több válaszadó az élőhely-csökkenés okát is megfogalmazta, így említésre kerültek a beépítések, az útépítés, a legelők és rétek felszántása, valamint az állattartás hiánya. A megmaradt élőhelyek méhlegelő értéke romlásának okát is megjelölték: ezek a nem megfelelő kezelés, a vegyszeres gyomirtás, valamint különösen gyakran említett ok a kaszálás túlzott mértéke és túl korán, a virágzási időben való időzítése. A túlzásba vitt kaszálás közvetett okaként több válaszadó a közmunkaprogramot nevesítette.

„Egyre több a beépitett terület, igy kevesebb a virágos terület, a jó méhlegelö." "Virágzás elött lekaszálnak réteket rendeletre, parancsra." 
A fentihez szorosan kapcsolódva további 19 válasz (1C) a vadvirágok sokféleségének és mennyiségének változására vonatkozik. Ezek egy része a vadvirágokat általánosságban említi (vadvirágok, virágzó növények), más része konkrét fajokat (kökény (Prunus spinosa L.), galagonya (Crataegus monogyna Jacq.), aranyvesszö) nevez meg. A szöveges válaszok egyöntetüen jelzik azt a tendenciát, hogy a vadvirágok faji sokfélesége és mennyisége csökkent.

„A méheknek rendkivüli mértékben elfogyott a változatos virágpor-forrása." „gyakori a hordás nélküli ido",

A válaszok egy csoportja (14) a (1D) növényvédelmet (ideértve a rovarirtókat és gyomirtókat) mint káros tényezőt önmagában, élőhelyi kontextustól függetlenül említi. A válaszok által jelzett tendenciák ebben az esetben is egységesek, a vegyszeres növényvédelem mennyiségére (túl sok) és felhasználási módjára (helytelen használat, rossz időzítés) utalnak.

„Jó családokat vittem repcére. Három nap elteltével több kaptárt üresen hazavittem, mert a méh elfogyott. Folyamatosan, a nap minden szakában (délben is) láttam a permetezést."

Harmincöt válasz jelölte meg (1E) a fásszárú méhlegelők (erdők, gyümölcsösök, fasorok) változását. A válaszok tartalma az előzőekhez képest kevésbé mutat egységes tendenciát, aminek feltehetően a régión belüli változatosság az oka. Általánosságban az erdőket, illetve specifikusan az akácosokat, valamint a gyümölcsösöket illetően is érkeztek válaszok a rendelkezésre álló terület csökkenésére és növekedésére is. Négy válaszadó emelte ki a szelídgesztenye megritkulását.

33 olyan válasz érkezett, amely az (1F) éghajlat változására és az ezzel kapcsolatos fenológiai változásokra utalt. Ezek a válaszok nagymértékben egységesek voltak, nem találtunk egymásnak ellentmondó megfigyeléseket. A következő időjárási tendenciákat érzékelték a válaszadók: megnövekedett az átlaghőmérséklet és változott az egyes évszakok időjárása, a tél enyhébb, a tavasz korábban érkezik. Jellemzőek a szélsőségek hőmérséklet (tavaszi fagyok) és csapadék (tavaszi csapadék, belvíz, nyári aszály) terén. Ezzel összefüggésben állnak a fenológiai változások, mint a korábban kezdődő virágzás, valamint a virágzási sorrend változása (egyszerre nyílnak régebben egymás után virágzó fajok).

„Egyre korábban nyílik az akác. A méhek nem fejlödnek fel." 
Annak ellenére, hogy az 1. kérdés kifejezetten a tájváltozásra vonatkozott, nagyszámú (23) válasz fogalmazta meg a (1G) méhészeti ágazat belső változásait, kiemelve a megnövekedett méhsürüséget és az ezzel járó méhbetegségek terjedését, valamint helyenként a méhlegelő túlterhelését.

„Nagyon megnövekedett a méhsürüség.”

\section{Méhcsaládok vándoroltatása}

A 2. kérdésre a válaszadók összesen 10 növényfajt vagy funkcionális egységet képező fajcsoportot (pl. gyümölcsfák) említettek vándorlásuk célpontjaiként, ezeket az 1. táblázat tartalmazza. A táblázatban a két megadott időperiódusra külön-külön jelöltük, hogy az adott időszakban aktívan vándorló méhészek hány százaléka vándorolt az egyes fajokra abban a periódusban. Az aktívan vándorló méhészek számát a kérdőív első, általános részének válaszai alapján kaptuk meg.

1. táblázat. Dél-dunántúli méhészek vándorlásának célpontjai két adott időperiódusban (1985-

2005 és 2005-2015) aktívan vándorló méhészek százalékában.

\begin{tabular}{lcc}
\hline \multicolumn{1}{c}{ Vándorlási célfaj } & $\begin{array}{c}\text { 1985-2005 között aktívan } \\
\text { vándorló méhészek \%-a }\end{array}$ & $\begin{array}{c}\text { 2005-2015 között aktívan } \\
\text { vándorló méhészek \%-a }\end{array}$ \\
\hline Akác (Robinia pseudoacacia L.) & 15,5 & 34,9 \\
Repce (Brassica napus L.) & 14,1 & 29,5 \\
Napraforgó (Helianthus annuus L.) & 8,5 & 25,6 \\
Hárs (Tilia spp.) & 15,5 & 20,9 \\
Selyemfü (Asclepias syriaca L.) & 9,9 & 7,0 \\
Aranyvessző (Solidago canadensis L.) & 7,0 & 7,8 \\
Szelídgesztenye (Castanea sativa Mill.) & 1,4 & 6,2 \\
Facélia (Phacelia tanacetifolia Benth.) & 1,4 & 4,7 \\
Medvehagyma (Allium ursinum L.) & 2,8 & 2,3 \\
Gyümölcsfák & 1,4 & 1,6 \\
\hline
\end{tabular}

A méhek által preferált vadvirágok

A 3. kérdés a háziméhek által szívesen látogatott vadvirágok felsorolását kérte, és ebben a tekintetben - szemben a 2. kérdéssel - nem tett különbséget a jelen időszak és az elmúlt 3 évtized között. Összesen 19 fajt vagy funkcionális fajcsoportot említettek a méhészek, ezeket a 2. táblázat tartalmazza. A táblázatban jelöltük az egyes fajok említési gyakoriságát, vagyis, hogy adott fajt összesen hány méhész említette. A 19 faj vagy fajcsoport nem mindegyike szigorú értelemben vett vadvirág, például a bükköny (Vicia spp.) és a lucerna (Medicago spp.) előfordul másodvetésben is, illetve a mogyoró (Corylus avellana L.) és a szeder 
2. táblázat. A méhek által szívesen látogatott vadvirágok (fajok vagy fajcsoportok) és összes említésük száma.

\begin{tabular}{lc}
\hline \multicolumn{1}{c}{ Méhek által kedvelt vadvirágok } & Említések száma \\
\hline Tarlóvirág (Stachys annua L.) & 53 \\
Pitypang (Taraxacum officinale (L.) Weber ex F.H. Wigg) & 31 \\
Mogyoró (Corylus avellana L.) & 27 \\
Árvacsalán (Lamium spp.) & 26 \\
Füzek (Salix spp.) & 26 \\
Herefélék (Trifolium spp.) & 20 \\
Menta (Mentha spp.) & 8 \\
Pipacs (Papaver rhoeas L.) & 8 \\
Búzavirág (Centaurea cyanus L.) & 7 \\
Hóvirág (Galanthus nivalis L.) & 7 \\
Bükköny (Vicia spp.) & 7 \\
Galagonya (Crataegus monogyna Jacq.) & 5 \\
Lucerna (Medicago spp.) & 5 \\
Éger (Alnus glutinosa L.) & 4 \\
Szeder (Rubus fruticosus L.) & 4 \\
Bogáncs (funkcionális csoport, Carduus, Cirsium, Dipsacus, Echinops & 3 \\
spp. stb.) & 3 \\
Gólyahír (Caltha palustris L.) & 3 \\
Borostyán (Hedera helix L.) & 3 \\
Kökény (Prunus spinosa L.) & 3 \\
Ibolya (Viola spp.) & 3 \\
\hline
\end{tabular}

(Rubus fruticosus L.) is állhat termesztésben. Mivel ezek egyike sem fö termény hazánkban, viszont mindegyikük előfordul vadon is, ezért kutatásunk kontextusában vadnövényként értelmeztük őket.

A nyári - ösz eleji idöszakban hiányzó méhlegelö növények

Míg a 3. kérdésben arra kértük a válaszadókat, hogy ne tegyenek különbséget a jelen időszak és az elmúlt évtizedek között, a 4. kérdés ezzel szemben kifejezetten a jelen időszakra vonatkozott. A méhészek azokat a fajokat sorolták fel, amelyek hiánya a méhlegelő értékének csökkenéséhez vezet a június és szeptember közötti időszakban. A fajokat a 3. táblázat tartalmazza. A táblázatban jelöltük az egyes fajok említési gyakoriságát, vagyis azt, hogy adott fajt összesen hány méhész említett. Ebben a kérdésben termesztett és vad növényeket is megadhattak a válaszadók. 
3. táblázat. A nyári - ősz eleji időszakban hiányzó méhlegelő növények (fajok vagy fajcsoportok) és összes említésük száma.

\begin{tabular}{lc}
\hline \multicolumn{1}{c}{ A nyári - ősz eleji időszakban hiányzó méhlegelő növények } & Említések száma \\
\hline Tarlóvirág (Stachys annua L.) & 43 \\
Aranyvessző (Solidago spp.) & 32 \\
Napraforgó (Helianthus annuus L.) & 15 \\
Herefélék (Trifolium spp.) & 12 \\
Facélia (Phacelia tanacetifolia Benth.) & 10 \\
Szelídesztenye (Castanea sativa Mill.) & 9 \\
Selyemfü (Asclepias syriaca L.) & 7 \\
Hárs (Tilia spp.) & 6 \\
Búzavirág (Centaurea cyanus L.) & 5 \\
Lucerna (Medicago spp.) & 5 \\
Bükköny (Vicia spp.) & 4 \\
\hline
\end{tabular}

Javaslatok a méhlegelö javitására

A nyitott kérdésre érkezett válaszok elemzése során azonosított témák nagymértékben átfednek az 1. kérdés során azonosított témákkal.

24 javaslat érkezett a $(5 \mathrm{~A})$ szántók kezelésére. A leggyakoribb javaslatok a tarlóhántás elkerülése vagy későbbre tolása, a tarlók másodvetése és vegyszerezésük kerülése, az ugaroltatás, a vetésforgó alkalmazása és a szántózöldítési program támogatása voltak.

„Aratás után a tarlót nem kéne tárcsázni." „Mezögazdálkodókkal közösen ugaroltatás, másodvetések (mustár, facélia)."

42 javaslat (5B) a szántón kívüli méhlegelő élőhelyek fenntartását, helyreálítását és megfelelö kezelését szorgalmazta. A válaszok több mint a fele, 22 válasz a kaszálás és a fontos méhlegelő fajok virágzási idejének összeegyeztetését javasolta, különös tekintettel az aranyvesszőre, amint azt 6 válaszadó ki is emelte. 8 méhész javasolta a rétek helyreállítását és hagyományos müvelésü fenntartását, de a legelők (4), parlagok (2), mezsgyék és szegélyek (2) valamint erdők (2) telepítésének igénye is felmerült.

„Vadnövények korai kaszálásának időeltolása, szolidágós területek későbbi kaszálása“" „A rétek, legelők helyreállitása, mert a közlegelőket kiosztották, felszántották. “

43 válasz (5C) méhlegelö fajok telepítését javasolta. Ezek többsége, 33 méhész virágzó lágyszárúak vetését, 10 méhész fák telepítését látná hasznosnak. 
Ketten gyógy- és füszernövények vetését javasolták. A következő termesztett fajok telepítésére érkezett javaslat (zárójelben az említések száma): facélia (6), herefélék (Trifolium spp.) (5), hajdina (Fagopyrum esculentum Moench.) (3), lucerna (3), köles (Panicum miliaceum L.) (1), mustár (Brassica nigra L.) (1), kakukkfú (Thymus spp.), oregánó (Origanum vulgare L.), levendula (Lavandula angustifolia Mill.), izsóp (Hyssopus spp.). Két méhész a tarlóvirág mint gyomnövény tudatos visszatelepítését szorgalmazná. Fás szárú méhlegelő fajok közül a szelídgesztenye igénye 3 alkalommal, a füz (Salix spp.), hárs, borbolya (Berberis spp.), som (Cornus spp.), császárfa (Paulownia tomentosa (Thunb.) Steud.) és kínai mézesfa (Tetradium daniellii T. G. Hartley) igénye 1-1 alkalommal került említésre.

„Jómagam fát és növényeket ültetek - Júlia borbolya, som, facélia, császárfa, kakukkfü, oregánó, gyógynövények, levendula, izsóp" „Mézontófüvet támogatni másodvetésben, tarlóba."

11 válasz a méhlegelők javítását (5D) más ágazatok megfelelő szabályozásában látta. Öten a parlagfü szabályozás, és ennek kapcsán rendeletben előírt kaszálás szigorán enyhítenének. Két méhész a közfoglalkoztatás keretében végzett kaszálás túlzott gyakoriságán változtatna. Az extenzív állattartás igénye 2, a szántóföldi gazdálkodókkal való jobb együttmüködés igénye 1 esetben merült fel. Egy válaszadó az idegenhonos fajok természetvédelmi kezelését a méhészeti érdekekkel egyeztetné.

"A gazdák és a méhészek érdekeit párhuzamositani" "a közmunkásoknak értelmes munkát adni"

Végül 9 válasz élőhelytől függetlenül szorgalmazta a (5E) vegyszerezés csökkentését, a gyomirtók és rovarirtók (virágzási időben történő) használatának viszszaszorítását.

\section{Értékelés}

A természetvédelmi szempontból ideális dombvidéki táj változatos élőhelytípusok gazdag mozaikja, ahol a fajok sokfélesége és a különböző célú emberi tájhasználati formák hosszú távon együtt tudnak fennmaradni. Az egyik jellegzetes dél-dunántúli tájhasználat a méhészet, amely nemcsak egy élőhelytípushoz, hanem azok együtteséhez kötődik, ezáltal - hasonlóan a természet védelméhez - táji léptékű. Ezt tükrözik a méhészeknek a tájjal, annak változásával és használatával kapcso- 
latos meglátásai és javaslatai. Az alábbiakban a megállapítások alátámasztására zárójelben feltüntetjük a kérdőív vonatkozó kérdéseinek számát, illetve az Eredmények fejezet megegyező számú alpontjait, valamint az 1. és 5. alpontok esetében megállapított kódokat.

Az utóbbi három évtizedben a méhészek által észlelt legfontosabb tájváltozások a mezőgazdasági területeken történtek (1A), és számos tájhasználati javaslat (5A) is a szántómüvelésre vonatkozik. Ugyancsak gyakori a szántóföldi termények és gyomok említése a méhlegelő növényfajok között $(2,3,4)$. Ez igazolja azt a statisztikai (Zilahy 2012) és szakirodalmi (Pinke \& Pál 2009) forrásokon nyugvó feltételezést, hogy a mai dél-dunántúli méhészek az akác mellett elsősorban a mezőgazdasági területeken tevékenykednek. Napraforgóra és repcére jóval többen vándoroltak az elmúlt tíz évben, mint az azt megelőző két évtizedben (2), ami alapján azt mondhatjuk, hogy a szántóknak a fent említett meghatározó méhészeti szerepe a Dél-Dunántúlon az utóbbi évtized során tovább nőtt. A napraforgón és repcén kívül fontos szántóföldi termesztésủ méhlegelö fajok a pillangósok (herefélék, bükköny, lucerna) és a facélia, ezekből a fajokból a méhészek szívesen látnának többet $(3,4)$. A szakirodalom hangsúlyozza, hogy a mezőgazdasági tájban nemcsak a fő szántóföldi termények, hanem a szántóföldi gazdálkodás változatossága, a szántókat tagoló kisebb élőhelyfoltok és a rajtuk élő vadnövények is kritikus fontosságúak a méhészek számára (Decourtye et al. 2011, Bretagnolle \& Gaba 2015, Requier et al. 2015). Ugyanez a megállapítás a kérdőívekben is egyértelmüen és következetesen megfogalmazást nyert (1A, 1B, 1C, 3, 4, 5A, 5B, 5C). A méhek által (a jelenben vagy a múltban) leginkább kedvelt szántóföldi vadvirág (3), csakúgy, mint a méhészek által a jelenben leginkább hiányolt méhlegelő faj (4) a tarlóvirág volt. Ez a faj ma már nagyon ritkán fordul elő, a múltban azonban az agrártájak meghatározó mézelö faja volt (Pinke \& Pál 2009), és még, úgy tünik, élénken él a méhészek emlékezetében. Így ez a növény nemcsak méhészeti, hanem kulturális jelentőséggel is bír.

A válaszokból kirajzolódik néhány olyan, több évtizedre visszamenő és a mezőgazdasági tájat érintő kedvezőtlen tendencia, ami miatt a méhészek mégsem tudják az abban rejlő potenciált kihasználni. Ezek a tendenciák - melyek a tarlóvirág visszaszorulásához is vezettek - alapvetően a mezőgazdaság intenzifikációjára vezethetök vissza (1A, 1B, 1C, 1D, 5A, 5B, 5C). A termesztett növények sokfélesége néhány fö termény javára csökkent, a pillangós zöldtakarmány vetése visszaszorult. A nyár végi - kora őszi kritikus időszakban hiányoznak a másodvetések és a tarlók; valamint nem elég körültekintő a rovar- és gyomirtószerek használata. Ezek a tendenciák nemcsak a háziméhekre, hanem a vad beporzókra nézve is károsak. A nemzetközi szakirodalomban és szakpolitikákban globálisan és európai léptékben is megfogalmazódott, hogy ha csupán néhány termény hozamának 
rövid távú maximalizálására törekszünk az intenzifikáció által, az a beporzók populációinak károsodása és az ökológiai integritás sérülése révén, hosszútávon a fenntartható élelmiszerbiztonság kockáztatását vonhatja maga után (Dicks et al. 2016, Potts et al. 2016a,b).

A méhészek által megfogalmazott tájhasználati javaslatok reflektálnak az azonosított problémákra. A szántók méhbarátabbá tételét a következő intézkedések révén látják megvalósíthatónak $(5 \mathrm{~A}, 5 \mathrm{C}, 5 \mathrm{E})$ :

- tarlóhántás idejének későbbre tolása, a virággazdag szántóföldi gyomtársulások hosszabb idejü meghagyása,

- vetésforgó, ugaroltatás és másodvetés révén tudatos zöldítés,

- több pillangós takarmánynövény vetése,

- $\quad$ kisebb mértékü és körültekintőbb vegyszerezés,

- a tarlóvirág célzott visszatelepítése.

Ezek a javaslatok alátámasztják az Európai Unió agrár-környezetgazdálkodási és szántózöldítési programjainak célkitüzéseit (Bretagnolle \& Gaba 2015, Kovács et al. 2015) és nagymértékben átfednek az ökológiai intenzifikáció elemeivel (Kovács-Hostyánszki et al. 2017). A méhészet és a mezőgazdaság ebben a folyamatban természetes szövetséges, ennek a tudatosítása, következésképpen a gazdálkodókkal való hatékonyabb együttműködés igénye a felmérés egyik legfontosabb üzenete.

A szántók mellett sok más virággazdag élőhely - erdők, cserjések, rétek, legelők, parlagok, átmeneti élőhelyek (gyep- és erdősávok, útszélek, árokpartok és szegélyek) - is fontosnak bizonyultak a méhészek számára (1B, 1E, 5B). A hársfára vándorlók magas aránya például a jellegzetesen dél-dunántúli, őshonos és természetvédelmi szempontból is fontos hársfa-elegyes erdők méhészeti szerepét jelzi (2). A méhészek úgy látják, hogy a természetközeli élőhelyek méhlegelő értéke az utóbbi évtizedekben csökkent, elsősorban a tájhasználati változások miatti élőhely-átalakítások és a megmaradt élőhelyek nem megfelelő kezelése miatt (1B). Ugyanakkor a degradált élőhelyeken spontán terjedő néhány idegenhonos, invazív növény magasan reprezentált a méhészek által kedvelt méhlegelö fajok között $(2,4)$. Az akácra eredményeink alapján jóval többen vándorolnak az elmúlt évtizedben, mint az azt megelőző kettőben, de az aranyvessző és a selyemfú állományai is kedvelt vándorlási célpontok, bár utóbbi faj a területen nem gyakori (2). Aranyvesszőből viszont 32 válaszadó szívesen látna többet is a Dél-Dunántúlon, hiszen az nemcsak jó hozammal bír, hanem a kritikus nyár végi-őszi időszakban virágzik, így segítve a méhek téli felkészülését. Ezeknek a fajoknak a kezelése, spontán terjedésük engedése vagy megakadályozása egy potenciális konfliktusforrás a természetvédelem és a méhészet érdekei között (Vítková et al. 2017). 
Ugyanakkor a két ágazat számos közös célja is megfogalmazódott a válaszokban. $\mathrm{Az}$ erre vonatkozó legfontosabbak javaslatok a következők voltak (5B, 5E):

- magasabb élöhelyi és faji sokféleség fenntartása,

- tudatos törekvés a nagyobb virággazdagságra,

- legelők és rétek hagyományos használatú fenntartása,

- késői kaszálás,

- a vegyszeres gyomirtás visszaszorítása,

- valamint általánosságban az az elv, hogy ahol nem muszáj, nem avatkozunk be, hanem teret engedünk a természet folyamatainak, ,élni hagyjuk a természetet".

Az utolsó javaslat kapcsán érdemes lehet átgondolni a közmunkaprogramot is (5D). A program az utóbbi években sok hasznos tevékenységet tett lehetővé az önkormányzatok számára a területük rendezése, szebbé tétele érdekében, de érdemes lenne a program kereteiben végzett kaszálást egyeztetni a természetvédelem és méhészet szempontjaival, erre vonatkozó önkormányzati ajánlásokat megfogalmazni.

A méhészet közvetlenül ki van téve az időjárás szeszélyeinek, a mézhozamot évről évre nagymértékben befolyásolja az egyes növényfajok virágzási sikere. Az éghajlatváltozás következtében az időjárás szélsőségei, kiszámíthatatlansága nemcsak a virágok sokféleségét és mennyiségét, hanem a fajok virágzásának egymás utániságát is megváltoztatja (Bartomeus et al. 2011). A fenti megállapításokat kutatásunk eredményei is alátámasztják, a méhészek érzékelik, hogy korábbra tolódtak és megrövidültek a virágzási periódusok (1F). Mindez a korábbinál is nagyobb bizonytalanságnak teszi ki az ágazatot, növeli annak sérülékenységét. Ha sikerül elérni a méhlegelők mainál nagyobb élőhelyi és faji diverzitását, az nemcsak azt eredményezné, hogy a méhek több fajról tudnának érdemben gyüjteni, hanem az ágazat éghajlatváltozással szembeni rezilienciája, adaptációs képessége is nőne.

\section{Következtetések}

A méhészet kapcsán leggyakrabban felmerülő tájhasználati konfliktusok egyike a természetvédelemmel kapcsolatos: a két szektor érdekei ütközhetnek olyan inváziós növényfajokkal érintett területek kezelése kapcsán, amely fajok méhészeti jelentősége magas, ám természetvédelmi szempontból aggályosak. További lehetséges konfliktusok színterei az intenzív agrárgazdasági mủvelés alatt álló területek, amelyek alapvető fontosságúak a méztermelésben, ugyanakkor a nagy kiter- 
jedésủ homogén felületek és az azokon történő vegyszerhasználat miatt a méhekre nézve nemcsak kedvezőtlen életteret, de mérgezési veszélyt is jelenthetnek.

Eredményeink ugyanakkor a méhészet és természetvédelem, valamint a méhészet és mezőgazdaság érdekei és céljai között számos szinergiát, együttműködési lehetőségeket is mutatnak. A potenciális konfliktusokat ezekre a lehetőségekre építve, ágazatok közötti párbeszéddel, egyensúly keresésével lehet elkerülni, de legalább mérsékelni. A méhészet inváziós fajokra való ráutaltságát számottevően csökkenthetik a méhészek által megfogalmazott javaslatok, amelyek révén a természetvédelmi szempontból kedvezőbb fajok és élőhelyek a mainál jobb méhlegelőt nyújthatnak, és ezáltal meghatározóbb szerepet játszhatnak a méhészeti tevékenységben. A mezőgazdaságban - tekintettel a háziméhek és vadon élő társaik fontos beporzó szerepére - érdemes lenne szélesebb körben alkalmazni a méheknek kedvező gazdálkodási formákat. A helyi szinten felmerülő tájhasználati konfliktusokat úgy lehet feloldani, hogy az érintettek bevonásával feltérképezzük a konkrét konfliktusos területeket és közösen kidolgozunk egy optimális tájhasználati struktúrát.

Köszönetnyilvánitás - Köszönet illeti a 17. Dunántúli Regionális Méhésztalálkozó szervezőit, amiért rendezvényükön teret adtak kutatásunknak, és mindenekelött köszönjük a 129 válaszadónak a kérdőívek kitöltésére fordított időt és figyelmet. K-H. Anikót a NKFI FK 123813 pályázat támogatta.

\section{Irodalomjegyzék}

Bartomeus, I., Ascher, J. S., Wagner D., Danforth, B. N., Colla, S., Kornbluth, S. \& Winfree R. (2011): Climate-associated phenological advances in bee pollinators and bee-pollinated plants. P. Nat. Acad. Sci. 108: 20645-20649. doi: http://dx.doi.org/10.1073/pnas.1115559108

Bretagnolle, V. \& Gaba, S. (2015): Weeds for bees? A review. - Agron. Sustain. Dev. 35: 891-909. doi: http://dx.doi.org/10.1007/s13593-015-0302-5

Clough, Y., Ekroos, J., Báldi, A., Batáry, P., Bommarco, R., Gross, N., Holzschuh, A., Hopfenmüller, S., Knop, E., Kuussaari, M., Lindborg, R., Marini, L., Öckinger, E., Potts, S., Poyry, J., Roberts, S., Steffan-Dewenter, I. \& Smith H. (2014): Density of insect-pollinated grassland plants decreases with increasing surrounding land-use intensity. - Ecol. Lett. 17: 1168-1177. doi: http:// dx.doi.org/10.1111/ele.12325

Czúcz, B., Molnár, Zs., Horváth, F. \& Botta-Dukát, Z. (2008): The natural capital index of Hungary. - Acta Bot. Hung. 50(Suppl.): 161-177. doi: http://dx.doi.org/10.1556/ABot.50.2008.Suppl.8

Decourtye, A., Alaux, C., Odoux, J.-F., Henry, M., Vaissière, B. \& Le Conte, Y. (2011): Why Enhancement of Floral Resources in Agro-Ecosystems Benefit Honeybees and Beekeepers? - In: Grillo, O. \& Venora. G. (eds.): Ecosystems Biodiversity. - InTech, Rijeka, Croatia, pp. 371-389.

Dicks, L., Viana, B., Bommarco, R., Brosi, B., Arizmendi, M., Cunningham, S., Galetto, L., Hill, R., Lopes, A. V., Pires, C., Taki, H. \& Potts, S. G. (2016): Ten policies for pollinators. - Science 354: 975-976. doi: http://dx.doi.org/10.1126/science.aai9226 
EC - European Commission DG Agriculture and Rural Development (2013): Evaluation of the CAP measures related to apiculture - Final Report. Framework Contract No. 30-CE-0219319/00-20, $170 \mathrm{p}$.

Kecskés, Cs. \& Kulcsár, R. (2002): A méhészet Magyarországon 2000-ben. - Statisztikai Szemle 80: 9 .

Kovács, M., Kránizt, L., Madarász, I., Magyari, R., Palakovics, Sz., Pethő, J., Rezneki, R., Szabó, E., Szerletics, Á., Sztahura, E., Tengerdi, G. \& Zsemle, V. (2015): Zöldités. Gazdálkodói kézikönyv. - Nemzeti Agrárgazdasági Kamara, 76 p.

Kovács-Hostyánszki, A., Espíndola, A., Vanbergen, A. J., Settele, J., Kremen, C. \&, Dicks, L. V. (2017): Ecological intensification to mitigate impacts of conventional intensive land use on pollinators and pollination. - Ecol. Lett. 20: 673-689. doi: http://dx.doi.org/10.1111/ele.12762

Lehébel-Péron, A., Sidawy, P., Dounias, E. \& Schatz, B. (2016): Attuning local and scientific knowledge in the context of global change: The case of heather honey production in southern France. - J. Rural Stud. 44: 132-142. doi: http://dx.doi.org/10.1016/j.jrurstud.2016.01.005

Maderson, S. \& Wynne-Jones, S. (2016): Beekeepers' knowledges and participation in pollinator conservation policy - J. Rural Stud. 45: 88-98. doi: http://dx.doi.org/10.1016/j.jrurstud.2016.02.015

Mihók, B., Kiss, G., Kovács, E., Margóczi, K., Fabók, V. \& Kalóczkai Á. (2016): Ki mondja meg, mi a fontos? - Részvétel és természetvédelem. - Természetvédelmi Közlem. 22: 131-154. doi: http://dx.doi.org/10.20332/tvk-jnatconserv.2016.22.131

Molnár, Zs., Kovács-Hostyánszki, A., Sárospataki, M. \& Báldi A. (2015): Gondolatok a hazai méhészet és a globális beporzó-felmérés közös céljairól. - Előadás, XVII. Dunántúli Regionális Méhésztalálkozó. Kaposvár és Térsége Méhészeinek Egyesülete és Kaposvári Egyetem, 2015. január 24.

Nagy, P. (2005): Hazánk és az Európai Unió méhészeti ágazatának piaci helyzete és kereskedelme az uniós csatlakozás fényében. - Diplomadolgozat, Budapesti Gazdasági Föiskola Külkereskedelmi Főiskolai Kar, Külgazdasági szak, 88 p.

Pinke, Gy. \& Pál, R. (2009): Floristic composition and conservation value of the stubble-field weed community, dominated by Stachys annua in western Hungary. - Biologia 64: 279-291. doi: http://dx.doi.org/10.2478/s11756-009-0035-5

Potts, S. G., Imperatriz-Fonseca, V. L. \& Ngo, H. T. (Eds.) (2016a): The assessment report of the Intergovernmental Science-Policy Platform on Biodiversity and Ecosystem Services on pollinators, pollination and food production. - Secretariat of the Intergovernmental Science-Policy Platform on Biodiversity and Ecosystem Services, Bonn, Germany, 827 p.

Potts, S. G., Imperatriz-Fonseca, V., Ngo, H. T., Aizen, M. A., Biesmeijer, J. C., Breeze, T. D., Dicks, L. V., Garibaldi, L. A., Hill, R., Settele, J. \& Vanbergen, A. J. (2016b): Safeguarding pollinators and their values to human well-being. - Nature 540: 220-229. doi: http://dx.doi.org/10.1038/ nature20588

Requier, F., Odoux, J. F., Tamic, T., Moreau, N., Henry, M., Decourtye, A. \& Bretagnolle, V. (2015): Honey bee diet in intensive farmland habitats reveals an unexpectedly high ower richness and a major role of weeds. - Ecol. Appl. 25: 881-890. doi: http://dx.doi.org/10.1890/14-1011.1

Stoate, C., Báldi, A., Beja, P., Boatman, N. D., Herzon, I., van Doorn, A., de Snoo, G. R., Rakosy, L. \& Ramwell, C. (2009): Ecological impacts of early 21 st century agricultural change in Europe - a review. - J. Environ. Manage. 91: 22-46. doi: http://doi.org/10.1016/j.jenvman.2009.07.005

Tóth, P. (2012): Magyar Méhészeti Nemzeti Program Környezetterhelési Monitoring vizsgálat 2011-2012. - Országos Magyar Méhészeti Egyesület, Veszprém, 48 p.

Vandenberg, A. J. \& the Insect Pollinators Initiative (2013): Threats to an ecosystem service: pressures on pollinators. -Front. Ecol. Environ. 11: 251-259. doi: http://dx.doi.org/10.1890/120126 
Vítková, M., Müllerová, J., Sádlo, J., Pergl, J. \& Pyšek, P. (2017): Black locust (Robinia pseudoacacia) beloved and despised: A story of an invasive tree in Central Europe. - Forest Ecol. Manag. 384: 287-302. doi: http://doi.org/10.1016/j.foreco.2016.10.057

Zilahy E. (szerk.) (2012): A méhészet, méztermelés helyzete és lehetöségei, különös tekintettel Észak-Magyarország megyéire. - Központi Statisztikai Hivatal, Budapest, 15 p.

\title{
Land use, land use change and the ideal bee pasture in the perception of beekepers from Southern Transdanubia, Hungary
}

\author{
Ildikó Arany ${ }^{1,2}$, Bálint Czúcz ${ }^{1,3}$, Imre Csonka ${ }^{4}$, Anikó Kovács- \\ Hostyánszki ${ }^{1}$ and Zsolt Molnár ${ }^{1}$ \\ ${ }^{1}$ MTA Centre for Ecological Research, \\ H-8237 Tihany, Klebelsberg K. u. 3, Hungary \\ ${ }^{2}$ Szent István University, Environmental Sciences PhD School, \\ H-2100 Gödöllö, Páter Károly u. 1, Hungary \\ ${ }^{3}$ European Topic Centre on Biological Diversity, Muséum national d'Histoire naturelle, \\ FR-75231 Paris, 57 rue Cuvier, Paris Cedex 05, France \\ ${ }^{4}$ Hungarian Beekeepers Association, \\ H-1094 Budapest, Viola u. 50, Hungary \\ e-mail:arany.ildiko@okologia.mta.hu
}

What makes a landscape ideal for bee pasture? What is the current situation compared to that, how could it be improved and what consequences would it involve concerning nature conservation? These are a few of our questions asked from 129 beekeepers during the Transdanubian Regional Beekepers' Conference in 2015, in Kaposvár, Hungary. Beyond the crops and forests as main sources of profit, most beekeepers regarded the role of diverse habitats rich in wild flowers extremely important for the health of the bee colony. Beekeepers formulated several recommendations on how to improve bee pastures, such as restoration of semi-natural habitats, conscious sowing of melliferous plants and greening of agriculture. Besides their benefits for apiculture, some of the recommended measures are beneficial for nature conservation too, because they enhance species and habitat diversity not only for the benefit of honeybees but also for that of wild pollinators.

Keywords: honeybee, pollination, invasive plant species, intensive agriculture, species richness, habitat diversity, local knowledge 